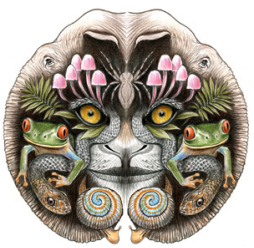

ISSN

Online 0974-7907

Print 0974-7893

OPEN ACCESS

\title{
MACROfungal DIVERSITY IN THE WeSteRn GHATS, KeRALA, INDIA: MEMBERS OF RUSSULACEAE
}

\author{
C. Mohanan
}

Division of Forest Health, Kerala Forest Research Institute, Peechi, Kerala 680653, India mohanan@kfri.org

Abstract: A macrofungal biodiversity inventory carried out in different forest ecosystems viz., west coast tropical evergreen forests, west coast tropical semi-evergreen forests, south Indian moist deciduous forests, southern subtropical broadleaved hill forests, southern montane wet temperate forests (shola forests), southern tropica dry deciduous forests, grasslands, Myristica swamp forests, and forest plantations falling in different forest divisions in the Western Ghats, Kerala employing opportunistic as well as fixed-size plot sampling methods from 2006-2011 yielded several rare and hitherto unrecorded macrofungi. In Russulaceae 15 species of macrofungi belonging to the genera Russula and Lactarius were recorded. Of these, 12 species of Russula viz. Russula aciculocystis, R. adusta, $R$. atropurpurea, $R$. cinerella, $R$. congoana, $R$. delicula, $R$. hygrophytica, $R$. luteotacta, $R$. mariae, $R$. martinica, $R$. michiganensis and $R$. periglypta and white coloured latex exuding Lactarius nebulosus are new records for the Western Ghats. All the Russulaceae members exhibit an ectomycorrhizal association with tree species like Hopea ponga, H. parviflora, Myristica malabarica, Vateria indica, Calophyllum apetalaum, among others.

Keywords: Lactarius, macrofungal diversity, Russulaceae, Russula, Western Ghats.

Macrofungi are an important component of the forest ecosystems and play a major role in ecosystem dynamics, such as litter decomposition, nutrient cycling and nutrient transport. Most macrofungi are saprobes, a few are ectomycorrhizal and some are pathogens of woody plants, insects and fungi. Many of them are edible, while a few are hallucinogenic, medicinal, toxic or poisonous. Macrofungal diversity, as with all other subsects of biodiversity, exhibits distinct patterns in both space and time. Such fungal diversity patterns are, to a large extent, unexplored. Recently, systematic studies were undertaken by the authors to understand the ecology, diversity, distribution, taxonomy and economic potential of macrofungi in different forest ecosystems in the Western Ghats. The study reveals that the Western Ghats is endowed with a remarkably rich macro-fungal flora. Moist-deciduous and semi-evergreen forests support a maximum number of macrofungi followed by evergreen and shola forests. Macro-fungal assemblage, species abundance and frequency were very characteristic of shola forests and Myristica swamps. Terricolous, humicolous and lignicolous macro-fungi form the major group. A total of 166 genera and 550 species falling in 51 families belonging to Basidiomycota and Ascomycota were encountered and of these, a large number of genera and species are reported for the first time from India (Mohanan 2011). In the present paper, taxonomical, ecological and diversity details of members of Russulaceae, viz., 13 species of Russula and two species of Lactarius are dealt with.

DOI: http://dx.doi.org/10.11609/JoTT.03620.5636-48

Editor: R.K. Verma, Tropical Forest Research Institute, Jabalpur, India

Date of publication: 26 April 2014 (online \& print)

Manuscript details: Ms \# o3620 | Received 13 May 2013 | Final received 19 March 2014 | Finally accepted 21 March 2014

Citation: Mohanan, C. (2014). Macrofungal diversity in the Western Ghats, Kerala, India: members of Russulaceae. Journal of Threatened Taxa 6(4): 5636-5648; http://dx.doi.org/10.11609/JoTT.o3620.5636-48

Copyright: (c) Mohanan 2014. Creative Commons Attribution 4.0 International License. JoTT allows unrestricted use of this article in any medium, reproduction and distribution by providing adequate credit to the authors and the source of publication.

Funding: Ministry of Environment and Forests (MoEF), Government of India, New Delhi.

Competing Interest: The authors declare no competing interests.

Acknowledgements: The author wishes to thank MoEF, Government of India, New Delhi, for financial assistance for carrying out the research. Field support provided by the staff of Kerala Forest Department and technical assistance by Mr. P.M. Sumesh, Mr. P. Rajesh and K.B. Anila are also acknowledged. 


\section{Materials and Methods}

Study areas were selected in the major types of forests, such as, western coast tropical evergreen forests, western coast tropical semi-evergreen forests, southern Indian moist deciduous forests, southern subtropical broadleaved hill forests, southern montane wet temperate forests (shola forests), southern tropical dry deciduous forests, grasslands, Myristica swamp forests, and forest plantations falling in different forest divisions in the Western Ghats of Kerala. Opportunistic sampling of macrofungi was carried out from as many habitats in the areas as possible. Fixed-size plot sampling (three sample plots of $100 \times 100 \mathrm{~m}$ in four locations, namely, Nilambur (moist deciduous forests), Iringole (semievergreen forests), Nelliampathy (evergreen forests), Mannavan Shola (shola forest) was also carried out to yield quantitative data. Sampling was carried out during both south-west and north-east monsoons and preand post-monsoon periods. These activities included: collecting sporocarps of macrofungi at the field site, labelling them, taking photographs, chemical spot tests, setting up spore prints, recording macro-morphological data in the illustrated data sheet, writing morphological descriptions, details on substratum, ectomycorrhizal status, host plants associated, processing the specimens for recording microscopic characters and identification of the specimens up to species level. Quantitative data on macrofungi were also recorded from the sample plots periodically for biodiversity analyses. Colours and chemical reactions of tissues and spores in water, $\mathrm{KOH}, \mathrm{NH}_{4} \mathrm{OH}, \mathrm{FeSO}_{4}, \mathrm{HCl}$, melzer's reagent, etc. were studied and used for identification of the taxa. Digital photomicrographs of the fungal structures were also made. The recent taxonomic concept based on the emerging information on molecular phylogenetic data has been followed and taxa have been rearranged accordingly (Kirk et al. 2008).

\section{Results}

In the present study, 13 species of Russula and two species of Lactarius were collected and identified up to the species level from different forest ecosystems of the Western Ghats, Kerala. Taxonomic details, distribution and ectomycorrhizal status, for each species are given below.

Russula aciculocystis Kauffman ex Bills \& O.K. Mill., Mycologia 76(6): 990 (1984) (Image $1 \mathrm{a}, \mathrm{b})$

Specimens examined: KFRI MF: 2165, 18.ix.2008, Ammayambalam, Arippa, Kerala; KFRI MF: 2293, 19.ix.2008, Arippa swamp forest, Arippa, Kerala.
Basidiome small to medium sized. Pileus $4-6.5 \mathrm{~cm}$ dia., hemispherical or convex with incurved margin when young, soon broadly convex to plane, finally plano-depressed; surface vivid red, violet brown (11E7) at centre, sticky when wet, sulcate striate at the margin, cuticle separable one-half to two-thirds way to disk, exposing the white or pale pinkish context below. Lamellae decurrent, close to sub-distant, forked near stipe, lamellulae rare, ventricose, up to $4 \mathrm{~mm}$ broad at mid radius, white when young soon pale buff; edge minutely fimbriate. Context white, unchanging. Stipe 2.5-5 cm x 8-12 mm, central, equal or tapered towards base, stuffed becoming hollow; surface white to pale pink, smooth. Annulus absent. Odour agreeable.

Spores 8.5-9.5 x 6.5-7.5 $\mu \mathrm{m}$, subglobose to broadly ovate; ornamentation amyloid, consisting of dense conical spines often fused to form short crusts which join to form fine to coarse more or less complete reticulum; suprahilar area ornamented as in rest of the spore; appendix non-amyloid. Basidia 40-47 x 14-16 $\mu \mathrm{m}$, clavate, hyaline, 4-spored. Cheilocystidia 40-55 x 9-14 $\mu \mathrm{m}$, lanceolate arising from the subhymenium. Pleurocystidia scattered, rare, 85-92 x 13-16 $\mu \mathrm{m}$, fusoid-ventricose or cylindrical. Subhymenium pseudoparenchymatous. Hymenophoral trama heteromorphous with sphaerocytes. Pileipellis

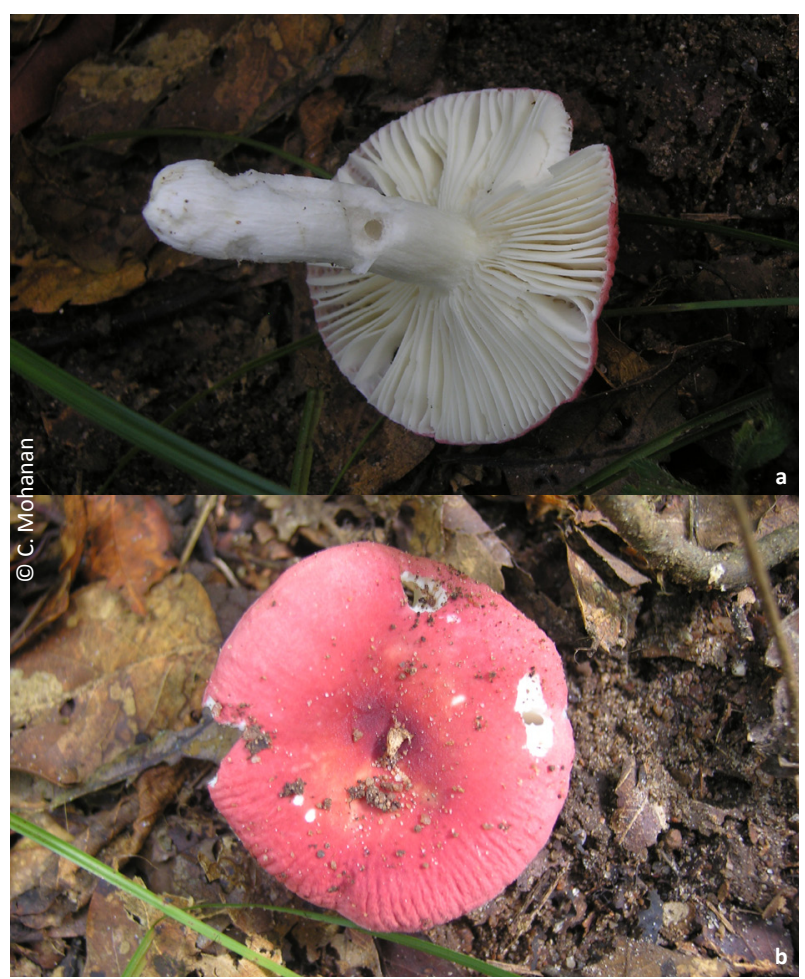

Image 1 a \& b. Russula aciculocystis 
consisting of loosely arranged, erect to sub-erect hyphae that terminate as short chains of cylindrical cells, tips of which are dermatocystidioid; sub-cutis gelatinized. Caulocystidia similar to cheilocystidia in size and shape. Clamp-connections absent in all tissues.

Russula aciculocystis is distributed in semi-evergreen to evergreen forests and occurs solitary or scattered on soil under Hopea ponga, H. parviflora, Myristica malabarica, Vateria indica, and Calophyllum apetalaum forming an ectomycorrhizal association.

Russula adusta (Pers.) Fr., Epicr. syst. mycol. (Upsaliae): 350 (1838) [1836-1838] (Image 2 a,b)

= Agaricus adustus Pers., Syn. meth. fung. (Göttingen) 2: 459 (1801)

= Omphalia adusta (Pers.) Gray, Nat. Arr. Brit. Pl. (London) 1: 614 (1821)

= Omphalia adusta (Pers.) Gray, Nat. Arr. Brit. Pl. (London) 1: 614 (1821) var. adusta

= Russula nigricans var. adusta (Pers.) Barbier, So. Sci. Nat. Sâon. 33(2): 91 (1907)

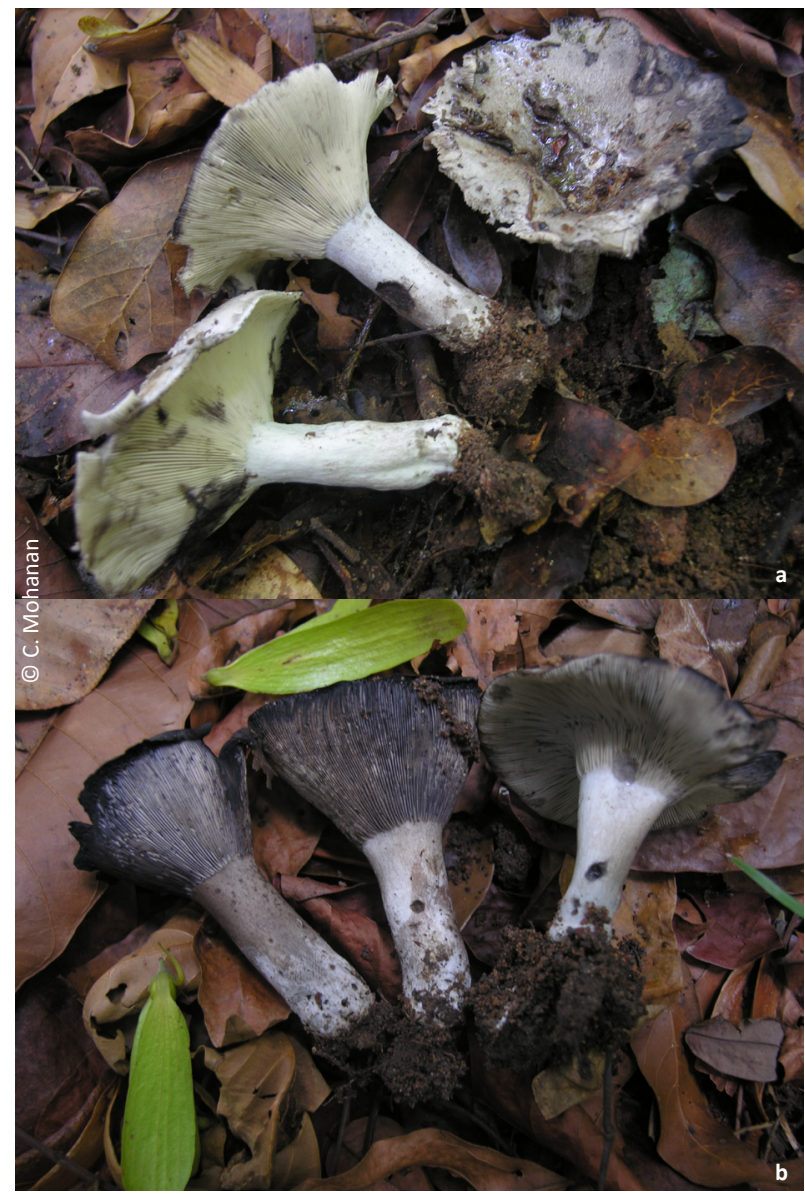

Image 2 a \& b. Russula adusta
Specimens examined: KFRI MF: 1760, 18.vi.2008, Chandhkkunnu, Nilambur, Kerala.

Basidiome medium to large sized. Pileus $4-8 \mathrm{~cm}$ dia., with a deep depression at centre at maturity; margin inrolled when young, becoming uplifted when fully expanded; surface dull white becoming grayishwhite then dark brown and finally black on handling or ageing, non-striate. Lamellae adnate, white turning black on handling, more or less crowded with lamellulae of different lengths, sometimes bifurcated close to the stipe; edge smooth, entire, stipe $3-6 \mathrm{~cm} \times 1-2 \mathrm{~cm}$, central equal, solid; surface chalky white, immediately turning black when handled. Odour not distinctive. Context white, discolouring blackish on exposure, heteromerous with nests of sphaerocytes.

Spores 7-8 x 5-6 $\mu \mathrm{m}$, globose to broadly ovoid, strongly amyloid with an ornamentation of prominent verrucae and connectives forming a partial reticulum; suprahilar plage inamyloid. Basidia clavate, 30-45 x 7-9 $\mu \mathrm{m}$, clavate, tetrasporate. Lamella-edge sterile with crowded macrocystidia, 58-80 x 6-9 $\mu \mathrm{m}$, clavate, mucronate with oleaginous refractive contents, discolouring black. Pleurocystidia similar. Hymenophoral trama heteromorphous with sphaerocytes. Pileipellis an ixocutis devoid of dermatocystidia. Caulocystidia 28-44 x 5-6 $\mu \mathrm{m}$.

Russula adusta is distributed in semi-evergreen to evergreen forests and occurs solitary or scattered on soil under Hopea ponga, H. parviflora, Myristica malabarica, Vateria indica, and Diospyros malabarica forming an ectomycorrhizal association. This species is characterized by blackening all the parts of the basidiome with age.

Russula atropurpurea (Krombh.) Britzelm., Bot. Zbl. 54: 99 (1893) (Image 3)

= Agaricus atropurpureus Krombh., Naturgetr. Abbild. Beschr. Schwämme (Prague) 9: 6 (1845)

= Russula atropurpurea var. krombholzii Singer, Beih. bot. Cbl. 49(2): 301 (1932)

= Russula depallens var. atropurpurea (Krombh.) Melzer \& Zvára, Arch. Prírodov. Výzk. Čech. 17(4): 10 (1927).

= Russula krombholzii Shaffer, Lloydia 33: 82 (1970)

= Russula undulata Velen., České Houby 1: 131 (1920)

Specimens examined: KFRI MF: 1629, 18.vi.2008, Chandhakkunnu, Nilambur, Kerala.

Basidiome small to medium sized. Pileus $3-8 \mathrm{~cm}$ dia., subglobose to convex, finally depressed, often lobed; surface bluish-red (12A7) to vivid red (11B6), yellowishred at the centre, weakly viscid when moist, shiny, smooth, not striate. Lamellae adnexed to adnate, white 


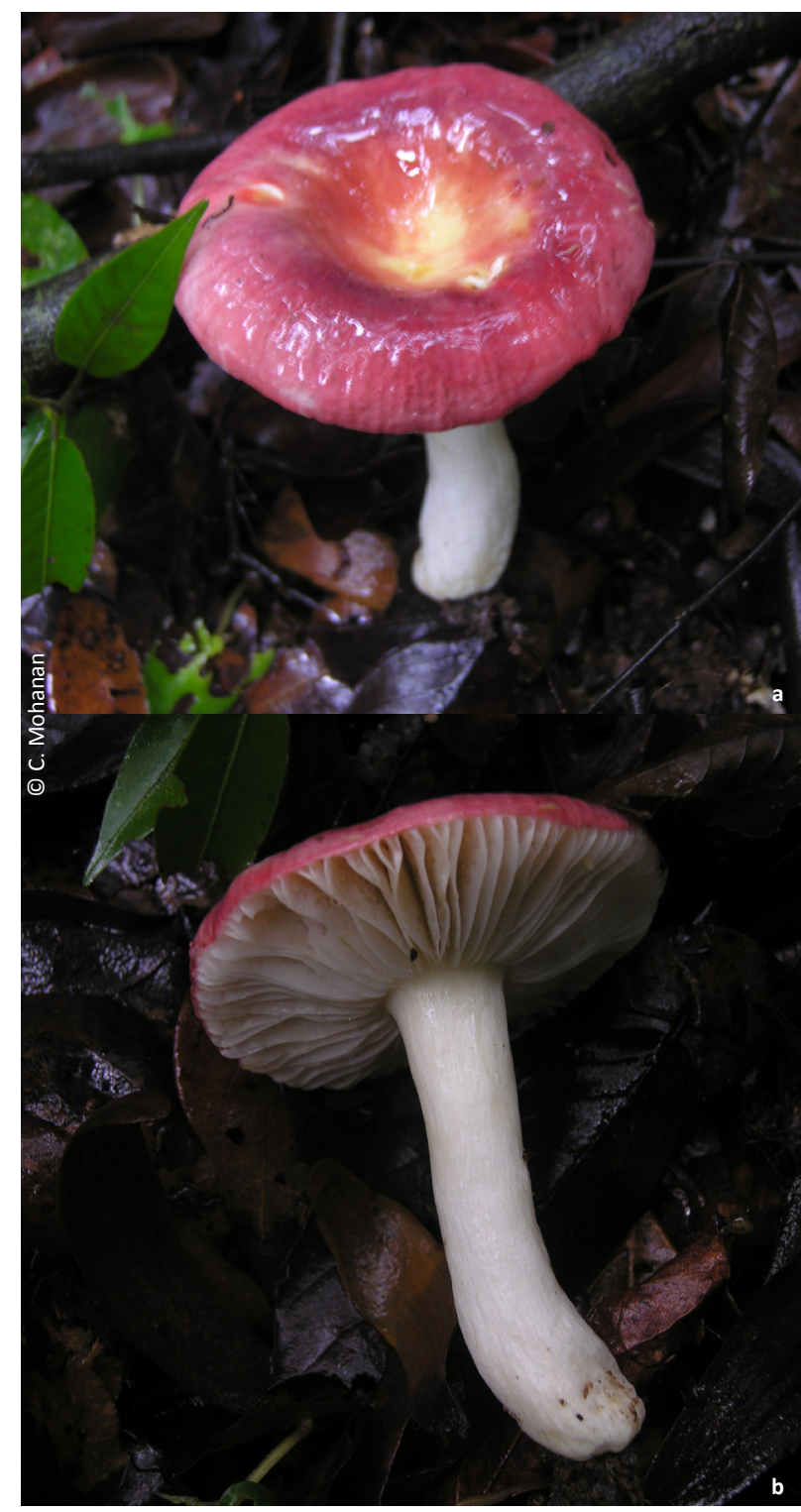

Image 3 a \& b. Russula atropurpurea

to pale pinkish, moderately crowded, with lamellulae, occasionally furcated. Stipe $2-5.5 \mathrm{~cm} \times 8-16 \mathrm{~mm}$, firm, cylindric, solid surface white with pinkish tints or grayish when moist. Context thick and firm white containing groups of large sphaerocytes; taste more or less acrid.

Spores 6-8 x 5.5-6 $\mu \mathrm{m}$ obovoid, hyaline, amyloid with fairly large verrucae connected by an incomplete, fine reticulum; suprahilar plage amyloid, often poorly defined. Basidia $24-28 \times 9-11 \mu \mathrm{m}$, clavate, bearing four sterigmata. Lamella-edge heteromorphous, with macrocystidia. Macrocystidia 40-48 x 8-15 $\mu \mathrm{m}$, fusoid, often mucronate, rarely clavate, hyaline, thin-walled, with granular oleaginous contents. Hymenophoral trama irregular and intermixed, hyaline, with thin-walled hyphae, 2-6 $\mu \mathrm{m}$ dia., and sphaerocytes. Subhymenial layer interwoven 5-8 $\mu \mathrm{m}$ wide. Pileal surface a loose trichodermium of erect, thin-walled hyphae, together with clavate or mucronate dermatocystidia, 30-80 x 5-7 $\mu \mathrm{m}$ with pigmented contents.

Russula atropurpurea is distributed in moistdeciduous to evergreen forests and sacred groves of the state. This species occurs solitary or scattered in large groups on soil under Vateria indica, Hopea parviflora stands.

Russula cinerella Pat., Bull. Mus. Hist. Nat., Paris 6: 527 (1924) (Image 4)

Specimens examined: KFRI MF: 3312, 18.vi.2009, Kuruva, Begur, Wayanad, Kerala.

Basidiome small to medium sized. Pileus $5-8 \mathrm{~cm}$ dia., convex to applanate, depressed at the centre; surface light grey to brownish-orange (6C4), silky, dry smooth; margin undulate and incurved. Lamellae adnate, white becoming pale yellowish, crowded, up to $5 \mathrm{~mm}$ wide. Stipe 4-6.5 cm x 10-16 mm, cylindric, solid; surface white, context up to $5 \mathrm{~mm}$ thick, white becoming pinkishbrown on exposure. Spore-print pale cream.

Spores 7-9 x 5-7 $\mu \mathrm{m}$, subglobose to ovoid, hyaline,

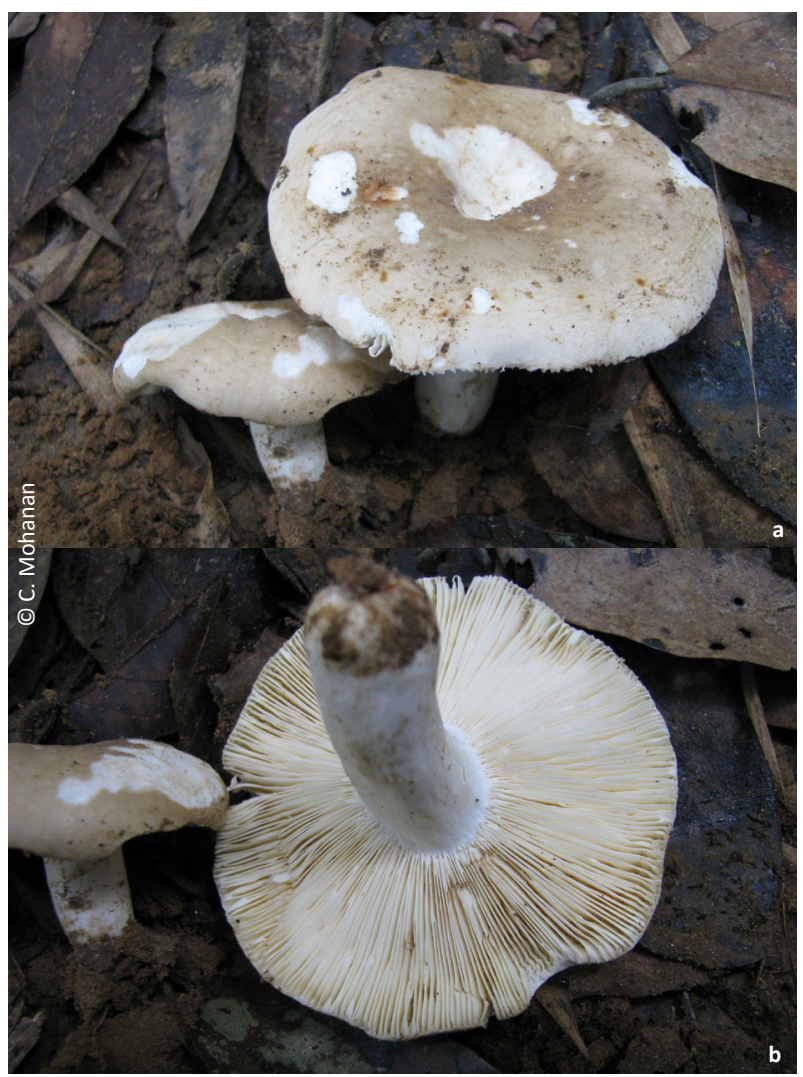

Image 4 a \& b. Russula aciculocystis 
ornamented with very fine, amyloid verruculae. Basidia 35-42 x 8-11 $\mu \mathrm{m}$, clavate, bearing four sterigmata. Lamella-edge heteromorphous. Cheilocystidia 26-35 x 9-12 $\mu \mathrm{m}$, cylindric to fusoid, often apically constricted or capitate, hyaline, with numerous refractive contents. Pleurocystidia 30-40 x 8-10 $\mu \mathrm{m}$, sinuous, lanceolate fusoid, often constricted or mucronate, with abundant granular contents. Hymenophoral trama irregular and intermixed. Pileal surface a disrupted trichodermium subtended by a broad hypodermium. Trichodermium of more or less erect hyphae, 2-3.5 $\mu \mathrm{m}$ dia., sometimes agglutinated into fascicles; dermatocystidia absent. Hypodermium 110-130 $\mu \mathrm{m}$ thick, of tightly interwoven hyphae, slightly agglutinated.

Russula cinerella is distributed in semi-evergreen to evergreen forests and sacred groves of the state. This species occurs solitary or scattered in large groups on soil under Vateria indica, Hopea parviflora, Diospyros malabarica stands.

Russula congoana Pat., Cryptog. Mycol. 30(3): 336 (1914) (Image 5 a,b)

Specimens examined: KFRI MF: 2381, 14.x.2008, Iringole Kavu, Perumbavoor, Kerala; KFRI MF: 2308, 20.ix.2008, Sanjeevani Vanam, Kulathupuzha, Kerala; KFRI MF: 3116, 15.vi.2009, Chandhakkunnu, Nilambur, Kerala.

Basidiome small to medium sized. Pileus 2-6 $\mathrm{cm}$ dia., at first convex then expanded with slight central depression; surface uniformly pastel red to red (10A5/10A7), smooth, finely striate at the margin, sticky. Lamellae adnate, white to pale cream exceeding the gills, up to $5 \mathrm{~mm}$ wide, close; edge entire, concolourous to the sides. Context thin, white. Stipe $2-4.5 \mathrm{~cm} \times 7-12$ $\mathrm{mm}$, central, cylindric, equal or slightly broader at the base, solid becoming stuffed and hollow; surface creamy white with a pinkish tint at the base, smooth. Annulus absent. Odour pleasant, taste not distinctive.

Spores 8-10 × 5-8 $\mu \mathrm{m}$, subglobose ellipsoid to oblong, densely ornamented with coarse, amyloid, verrucae interconnected by a reticulate system. Basidia clavate, 30-40 x 10-15 $\mathrm{mm}$, 4-spored. Macrocystidia scattered on both edges and sides of the lamellae, 35-50 x 10-12 $\mu \mathrm{m}$, clavate to fusiform, frequently mucronate, thin-walled. Subpellis slightly gelatinized. Suprapellis composed of erect, shortly cylindrical elements, 3-5 dia. Pileocystidia numerous, intermixed with hyphae, 35-200 x 4-8 $\mu \mathrm{m}$, cylindrical clavate to fusiform, obtuse or slightly constricted at large apex. Clamp-connections absent.

Russula congoana is distributed in moist-deciduous

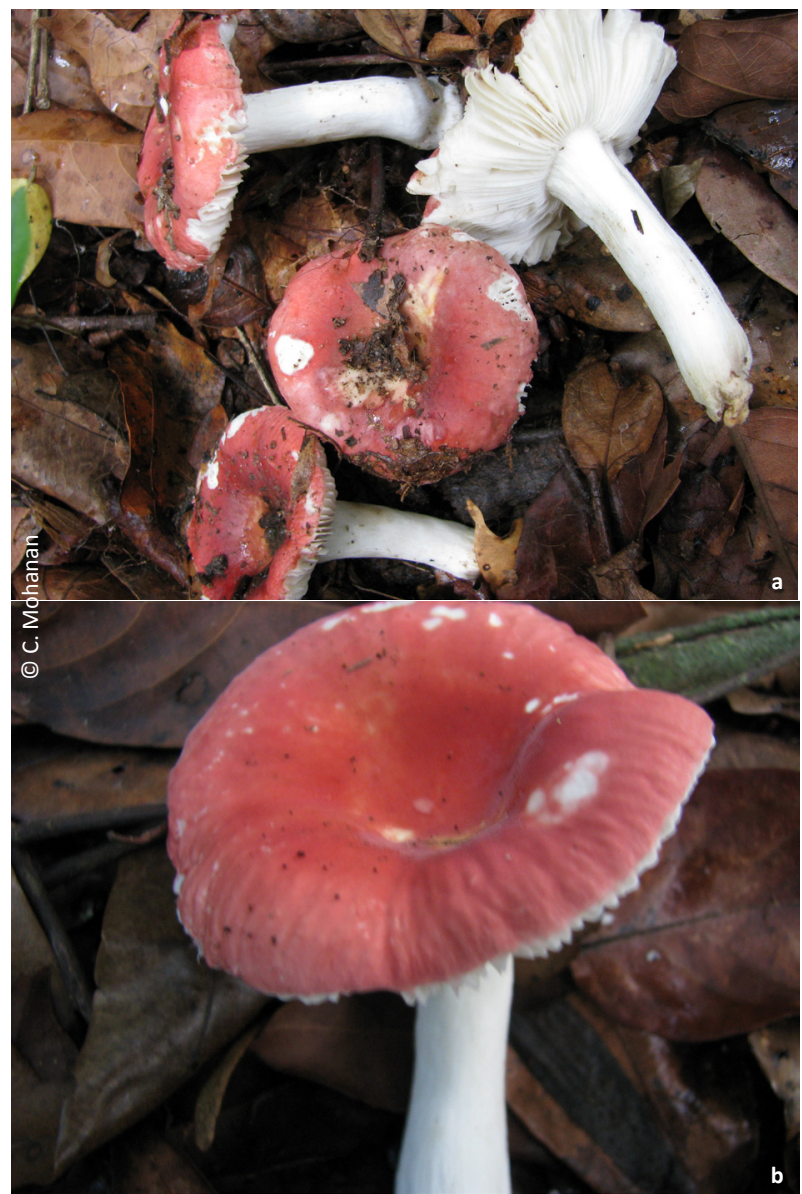

Image 5 a \& b. Russula congoana

to evergreen forests and occurs solitary or scattered on soil under Hopea ponga, $\mathrm{H}$. parviflora, Myristica malabarica, Vateria indica, and Diospyros malabarica forming an ectomycorrhizal association. This is a very striking species easily recognized by the pastel red pileus and the heavy ornamentation of the spores. This species is edible.

Russula delicula Romagn., Bull. trimest. Soc. mycol. Fr. 61: 37 (1945) (Image 6 a,b)

Specimens examined: KFRI MF: 3297, 18.vi.2009, Kuruva, Begur, Wayanad, Kerala.

Basidiome small to medium sized. Pileus $3-6 \mathrm{~cm}$ dia., convex becoming uplifted and infundibuliform at maturity; margin inrolled when young, becoming uplifted when fully expanded; surface yellowish-grey (3B2) with grayish-orange (5B3) tints, viscid when wet, otherwise dry, non-striate. Lamellae subdecurrent, white, up to $4 \mathrm{~mm}$ broad, often forked at or near the stipe, interveinose, white to pale buff, close, without lamellulae; edge smooth, entire. Context white. Stipe $1.5-3.5 \mathrm{~cm} \times 1.2-2 \mathrm{~cm}$, central, equal or slightly 


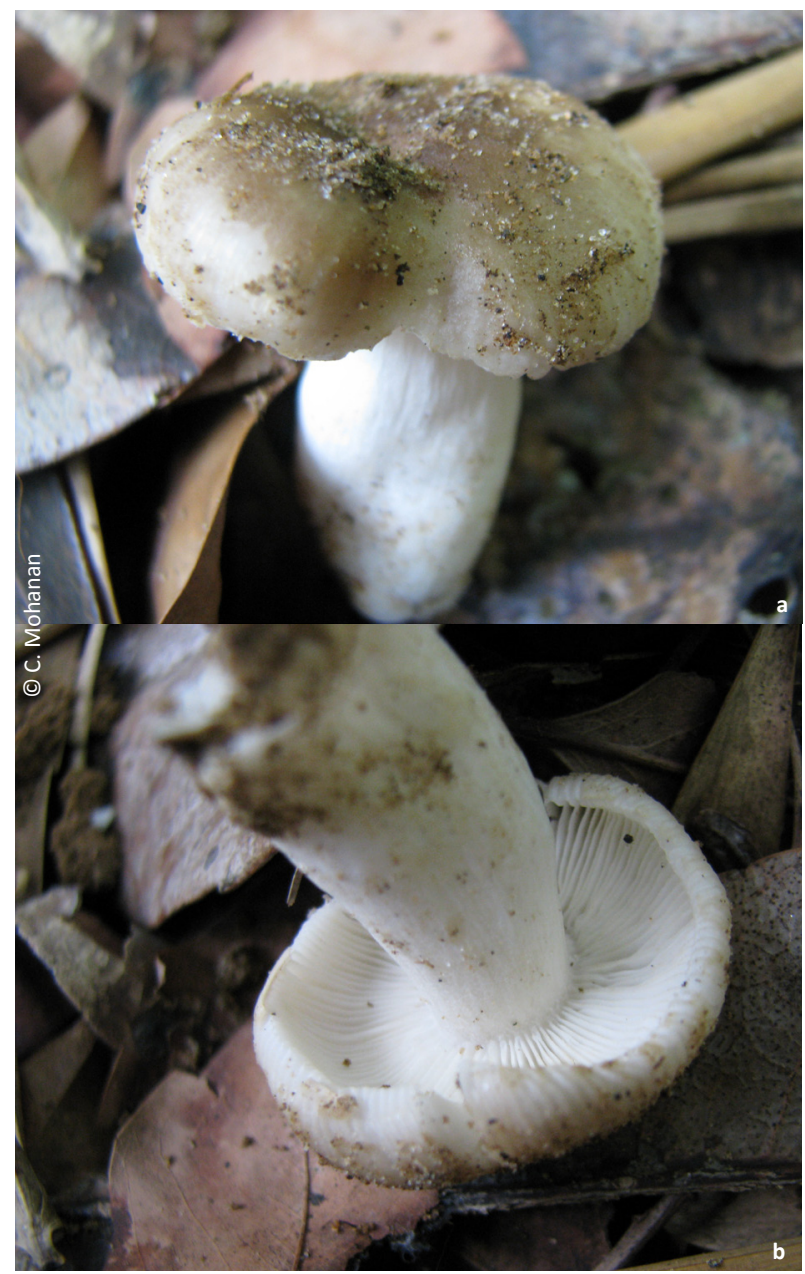

Image 6 a \& b. Russula delicula

attenuated below, solid; surface white, smooth. Annulus absent. Odour not distinctive.

Spores 7-10 x 6-7.5 $\mu \mathrm{m}$, globose to broadly ovoid, strongly amyloid with an ornamentation of moderately large verrucae and thin connectives forming a partial to complete reticulum. Basidia 35-40 x 5-7 $\mu \mathrm{m}$, clavate, tetrasporate. Cystidia scattered both on edges and sides of the lamellae, $80-110 \times 15-25 \mu \mathrm{m}$, clavatefusoid sometimes with a long, attenuated neck bearing a small bulb apically, filled with oleaginous refractive contents. Subhymenium pseudoparenchymatous. Hymenophoral trama heteromorphous. Pileipellis with horizontally arranged non-gelatinized hyphae, devoid of dermatocystidia.

Russula delicula is distributed in moist-deciduous to evergreen forests and occurs solitary or scattered on soil under Hopea ponga, H. parviflora, Vateria indica, and Diospyros malabarica forming an ectomycorrhizal association.
Russula hygrophytica Pegler, in Pegler \& Singer, Mycotaxon 12(1): 92 (1980) (Image 7 a,b)

Specimens examined: KFRI MF: 2359, 14.x.2008, Iringole Kavu, Perumbavoor, Kerala; KFRI MF: 2295, 20.ix.2008, Arippa, Kulathupuzha, Kerala.

Basidiome small to medium sized. Pileus $3-4.5 \mathrm{~cm}$ dia., convex, depressed at the centre; surface brownishorange (5C4) at centre, pale yellowish-brown elsewhere, viscid when moist, otherwise dry, radially plicate-sulcate half-way to the disk, sometimes disrupting to expose the white, underlying context; margin membranous, acute, fragile, at times fissile. Lamellae adnexed, whitish, moderately crowded, sometimes furcate near the stipe, distinctly interveined, with very few lamellulae. Stipe 2-5 x 0.5-9 cm, fragile, cylindric, hollow; surface off white, bruising grey or brownish at the base, glabrous. Context very thin, membranous, fragile, white, heteromerous, with thin-walled hyphae 2-4 $\mu \mathrm{m}$ dia., intermixed with numerous sphaerocytes, 10-26 $\mu \mathrm{m}$ dia., also scattered, isolated laticiferous elements, odour not distinctive,

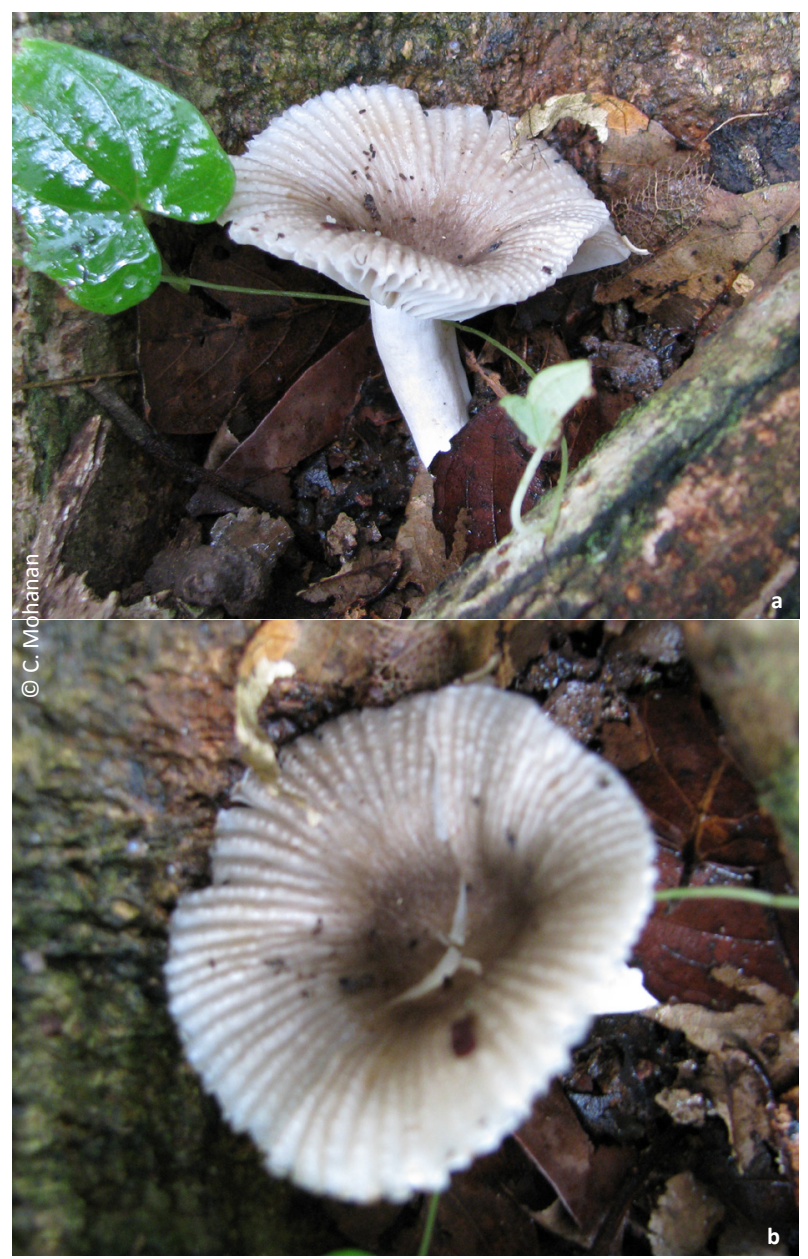

Image 7 a \& b. Russula hygrophytica 
taste mild or very slightly peppery.

Spores 6-10 x 5-9 $\mu \mathrm{m}$, globose to subglobose, hyaline, strongly amyloid, with a reticulate-cristate ornamentation almost forming a complete network; individual spines 0.5-1.5 x 0.2-0.6 $\mu \mathrm{m}$; hilar appendix hyaline, $1-2 \times 0.7-1 \mu \mathrm{m}$. Basidia 34-40 X 11-13 $\mu \mathrm{m}$, clavate-ventricose, with two or four sterigmata. Lamella-edge sterile. Cheilocystidia 22-35 x 6.5-8 $\mu \mathrm{m}$, clavate, mostly mucronate. Macrocystidia 62-76 x 7-9 $\mu \mathrm{m}$, mucronate or obtusely rounded, with granular contents. Hymenophoral trama heteromerous, hyaline, similar to the context. Subhymenial layer 10-12 $\mu \mathrm{m}$ wide, pseudoparenchymatous. Pileipellis complex; epicutis 35-80 $\mu \mathrm{m}$ thick, comprising a loose palisade of erect or semi-erect filamentous hyphae, 1-3 $\mu \mathrm{m}$ dia., together with numerous clavate to cylindro-clavate dermatocystidia, 10-30 x 4-5 $\mu \mathrm{m}$, arising from a broad cutis, 75-200 $\mu \mathrm{m}$ thick, with loosely woven hyphae and scattered laticiferous hyphae.

Russula hygrophytica is distributed in semi-evergreen to evergreen forests and sacred groves of the state. This species occurs solitary or scattered in large groups on soil often forms a ring under Vateria indica, Hopea parviflora stands.

Russula leelavathyi K.B. Vrinda, C.K. Pradeep \& T.K. Abraham, Mycotaxon 62: 389 (1997) (Image 8 a,b)

Specimens examined: KFRI MF: 2140, 17.ix.2008, Palode, Thiruvananthapuram, Kerala; KFRI MF: 2912, 03.vi.2009, Chandhakkunnu, Nilambur, Kerala; KFRI MF: 3647, 17.ix.2009, Kuruva, Begur, Wayanad, Kerala.

Basidiome small to medium sized. Pileus $3-6 \mathrm{~cm}$ dia., fleshy, convex then expanded with a central depression; surface uniformly ivory (4B3) to grayish-white, areolately cracked forming patches of ivory squamules on a off white ground, entire at the disk; margin radially plicatostriate for two-thirds of radius from the margin and cracking along radial striae to expose underlying white context below, gelatinized under wet weather. Lamellae adnexed to subdecurrent, white, up to $4 \mathrm{~mm}$ wide, crowded, lacking lamellulae. Context white, up to $4 \mathrm{~mm}$ wide, heteromerous, with thin-walled, hyaline hyphae, 2-6 $\mu \mathrm{m}$ wide, intermixed with sphaerocytes, 16-24 $\mu \mathrm{m}$. Stipe $2-5 \mathrm{~cm} \times 5-15 \mathrm{~mm}$, central cylindric, equal, solid becoming stuffed; surface white, smooth. Annulus absent. Odour not distinctive. Taste slightly acrid.

Spores 6-7.5 x 4.5-6.5 $\mu \mathrm{m}$, subglobose to broadly ovoid, hyaline with an ornamentation of coarse, amyloid, verrucae and scattered fine connectives forming a partial reticulum. Basidia clavate, 45-60 $x$ 9-11 $\mu \mathrm{m}, 4-$ spored. Lamella-edge sterile; cheilocystidia

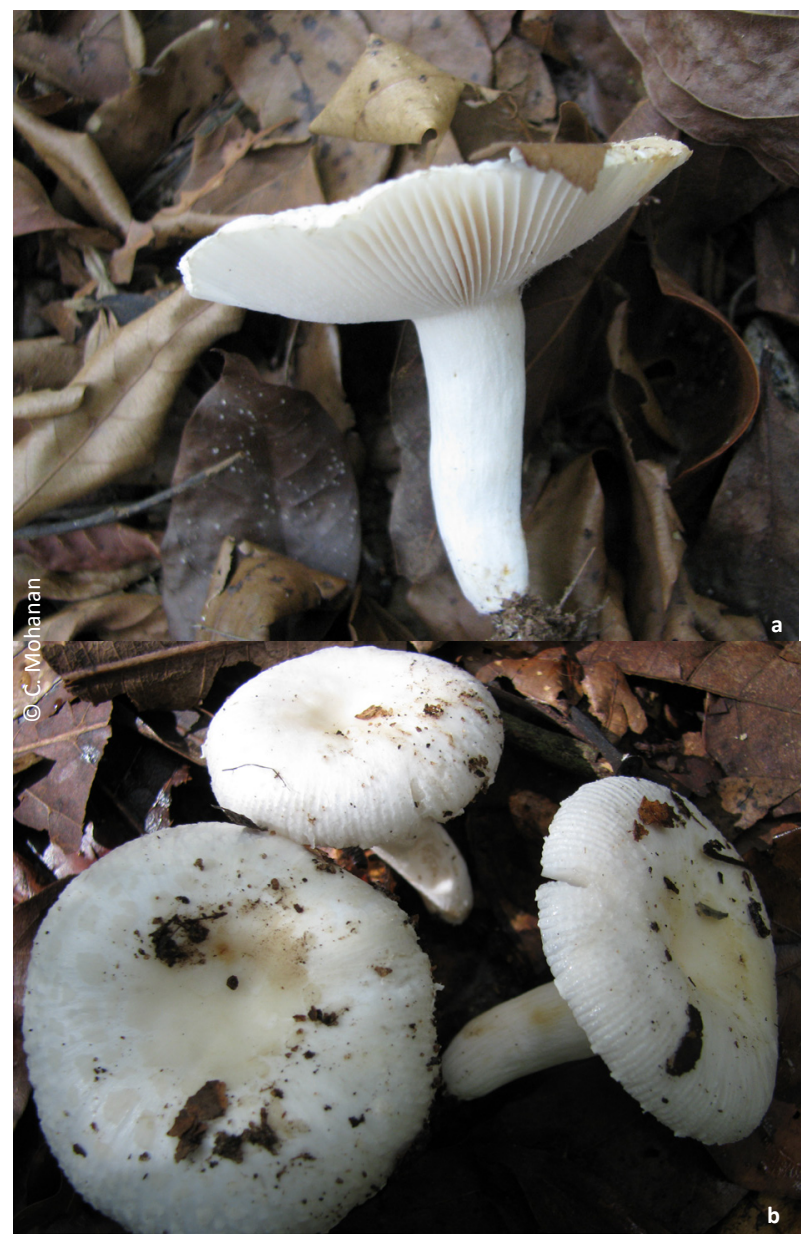

Image 8 a \& b. Russula leelavathyi

33-35 x 10-12 $\mu \mathrm{m}$, clavate fusoid, lageniform, often with acutely pointed or mucronate apex. Macrocystidia 70-90 x 5.5-7.5 $\mu \mathrm{m}$, ventricose, fusoid to acuminate, thin-walled, with granular contents, numerous both on sides and edges of the lamellae. Hymenophoral trama heteromerous composed of thin-walled, hyaline hyphae, intermixed with sphaerocytes. Pileipellis distinctly two layered; an upper epithelial layer and a lower loosely interwoven gelatinized layer. Stipitipellis with abundant caulocystidia, 20-40 x 7-12 $\mu \mathrm{m}$, similar to cheilocystidia

Russula leelavathyi is distributed in moist-deciduous to evergreen forests and occurs solitary or scattered in large groups on soil under Hopea ponga, H. parviflora, Vateria indica, and Diospyros malabarica forming an ectomycorrhizal association. The furcated lamellae together with lack of lamellulae are characteristic features of this species. This species is closely related to $R$. moyersoeni Buyck, in the overall habit and pigmentation but can be distinguished by virtue of the white pileus, smaller spores with a finer ornament, and lack of pileal macrocystidia and presence of caulocystidia. 
Russula luteotacta Rea, Brit. basidiomyc. (Cambridge): 469 (1922) (Image 9)

Specimens examined: KFRI MF: 2377, 14.x.2008, Iringole Kavu, Perumbavoor, Kerala.

Basidiome small to medium sized. Pileus $5-6 \mathrm{~cm}$ dia., fleshy, convex with a broad depression at the centre; surface greyish-red (9B6) to red (9B7) sometimes with white tints at places, sticky when wet, translucent striate at the margin, pellicle peels off easily up to mid radius; margin crenate, incised. Lamellae adnexed, appearing free when mature, pale yellow, crowded with out lamellulae, rarely bifurcated. Context white, unchanging, brittle. Stipe 3-4.5 cm x 5-9 mm, central, slightly broader at the base, stuffed; surface white, smooth with a faint red colour at apex and middle. Annulus absent. Odour agreeable. Spore-print pale yellow in mass.

Spores 7-8 x 6-6.5 $\mu \mathrm{m}$, subglobose, ornamentation moderately thick, forming a more or less complete reticulum, suprahilar area inamyloid. Basidia clavate, 38-45 x 10-11.5 $\mu \mathrm{m}, 4$ 4-spored. Lamella-edge heteromorphous; cheilocystidia and pleurocystidia macrocystidioid, rare, 47-58 x 8-11 $\mu \mathrm{m}$ broadly clavate with an apical projection which is filled with refractive contents. Subhymenium pseudoparenchymatous. Hymenophoral trama heteromorphous with abundant

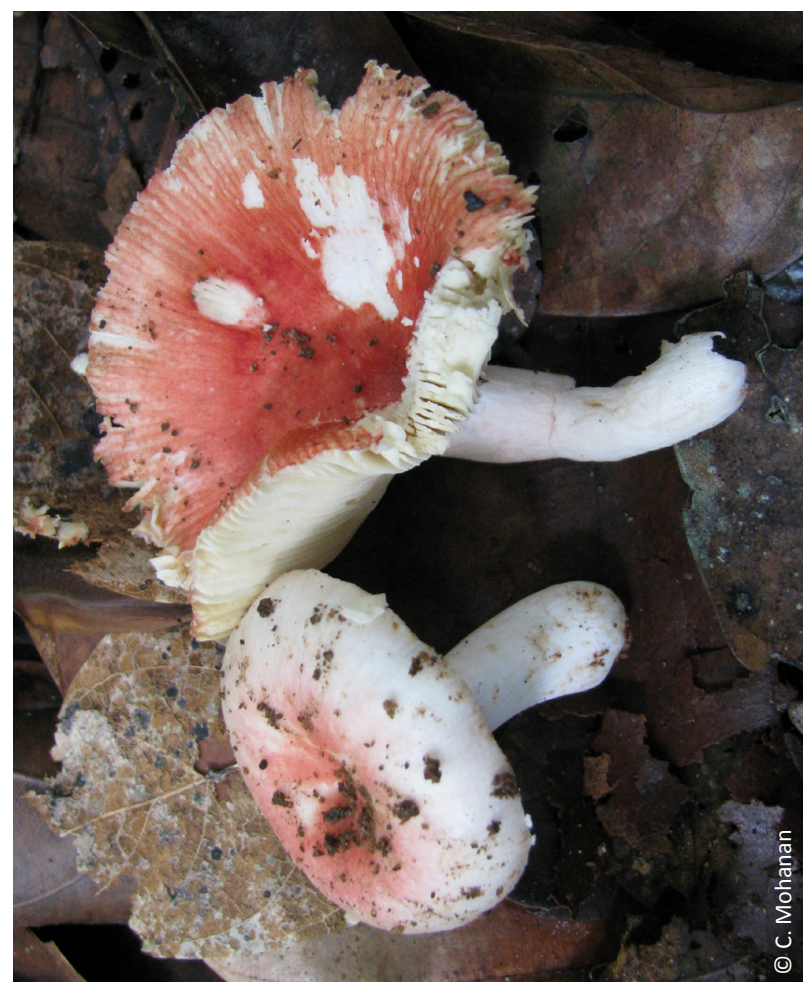

Image 9. Russula luteotacta sphaerocytes. Pileipellis a gelatinized trichodermium. Pileocystidia macrocystidioid.

Russula luteotacta is distributed in moist-deciduous to evergreen forests of the state. This species is poisonous and occurs solitary or scattered in small groups on soil under Hopea ponga, H. parviflora, Vateria indica, and Diospyros malabarica forming an ectomycorrhizal association.

Russula mariae Peck, Trans. \& Proc. Roy. Soc. S. Australia 43: 275 (1919) (Image $10 \mathrm{a}$,b)

Specimens examined: KFRI MF: 2265, 19.ix.2008, Shenkily, Kulathupuzha, Kerala; KFRI MF: 3641, 17.ix.2009, Kuruva, Begur, Wayanad, Kerala; KFRI MF: 3283, 18.vi.2009, Kuruva, Begur, Wayanad, Kerala.

Basidiome small to medium sized. Pileus $4.5-6.5 \mathrm{~cm}$ dia., convex becoming depressed; surface grayish-brown at centre, brownish-violet (11D8) to red (11A3) at the margin, uniformly becoming paler when old, smooth; margin radially striate. Lamellae adnate, crowded, often dichotomously branched, yellowish-white (2A2),

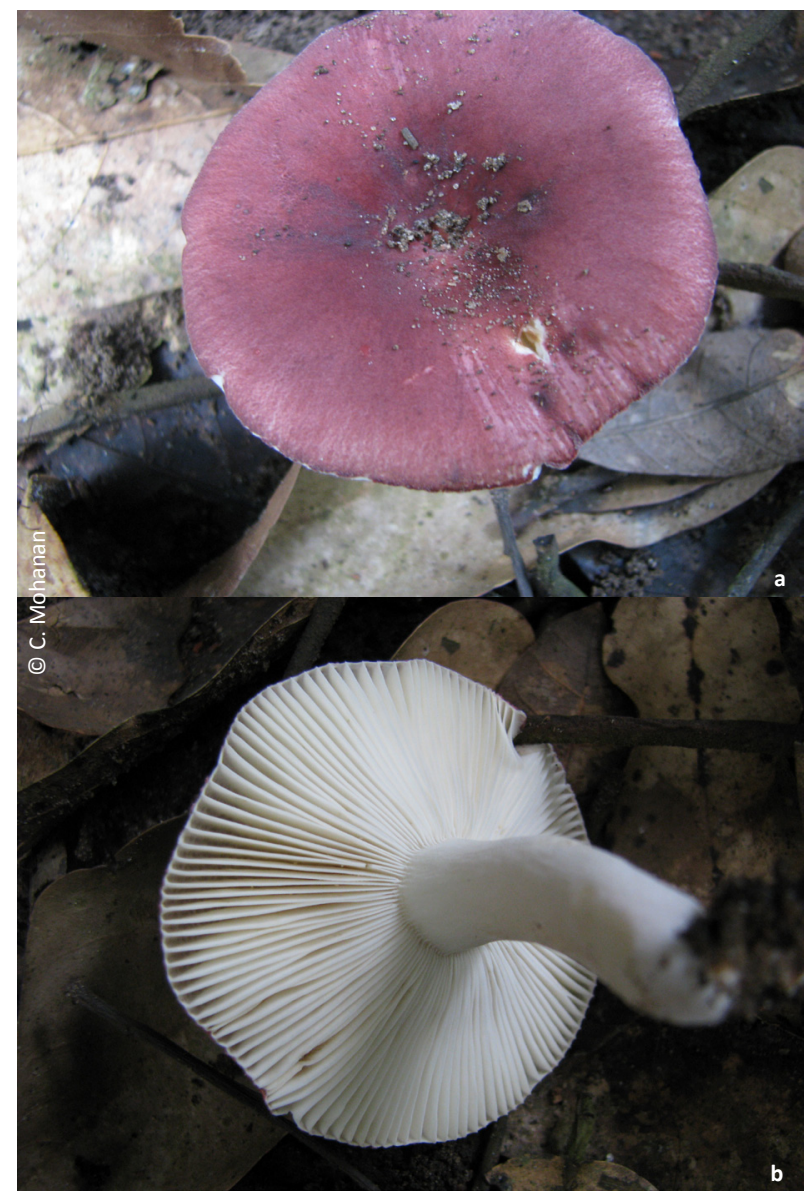

Image 10 a \& b. Russula mariae 
thick, without lamellulae. Context whitish to cream, unchanging when cut, heteromerous, with thin-walled hyphae, $1.5-5 \mu \mathrm{m}$ dia., and groups of sphaerocytes. Stipe 2.5-7 cm x 5-10 mm, central, cylindric, solid becoming hollow; surface pink with pale red tints, smooth.

Spores 8-9 x 6-7 $\mu \mathrm{m}$, globose to subglobose, strongly amyloid, consisting of irregular large verrucae, joined by connective to form a partial to complete reticulum, hilar appendix non-amyloid. Basidia 28-31 x 10-12 $\mu \mathrm{m}$, clavate bearing four sterigmata. Lamella-edge sterile, cheilocystidia crowded 35-45 x 10-11 $\mu \mathrm{m}$, ventricosefusoid, usually with acutely pointed or mucronate apex, thin-walled, hyaline. Pleurocystidia scattered, 78-90 x 15-20 $\mu \mathrm{m}$, ventricose-rostrate or fusoid-cylindric, thin-walled, hyaline. Hymenophoral trama intermixed, sphaerocytes and connective hyphae without laticifers. Subhymenium pseudoparenchymatous. Pileal cuticle a trichodermium of erect to semi-erect hyphae that terminate as short chains of inflated cells, terminal cells up to $54 \mu \mathrm{m}$ long, lanceolate, obclavate, often rostrate or narrowly to broadly lageniform, constituting the dermatocystidia. Stipitipellis a trichodermium, similar to pileus cuticle, caulocystidia 45-60 × 5-7.5 $\mu \mathrm{m}$, aciculate, lanceolate, subulate or fusoid-ventricose, thin-walled, hyaline. All hyphae lacking clamp-connections.

Russula mariae is distributed in moist-deciduous to evergreen forests of the state. This beautiful red coloured species occurs solitary or scattered in small groups on soil under Hopea ponga, H. parviflora, Hopea $\mathrm{sp}$. Vateria indica, and Diospyros malabarica forming an ectomycorrhizal association.

Russula martinica Pegler, in Pegler \& Singer, Mycotaxon 12(1): 94 (1980) (Image 11)

Specimens examined: KFRI MF: 1013, 04.v.2008, Chandhakkunnu, Nilambur, Kerala.

Basidiome small to medium sized. Pileus $3.5-6 \mathrm{~cm}$ dia., convex then expanded with a central depression; surface scarlet red to vivid red (9A8), pastel red at margin, dry, finely velutinate; margin acute, short sulcate, undulate. Lamellae adnate, pale yellow, 3-4 $\mathrm{mm}$ broad, moderately crowded, with lamellulae. Stipe 3-5 cm x 8-10 mm, robust, cylindric, fistulose then hollow; surface white to pale yellow, glabrous, rugose. Context 3-4 $\mathrm{mm}$ thick at the disk, white unchanging, heteromerous, with loosely woven, thin-walled hyphae, 2-8 $\mu \mathrm{m}$ dia., intermixed with abundant groups of sphaerocytes; odour faint; taste slightly acrid.

Spores 9-11 x 8-10 $\mu \mathrm{m}$, subglobose to obovoid, strongly amyloid, with an ornamentation of isolated verrucae, with no connectives; suprahilar plage amyloid.

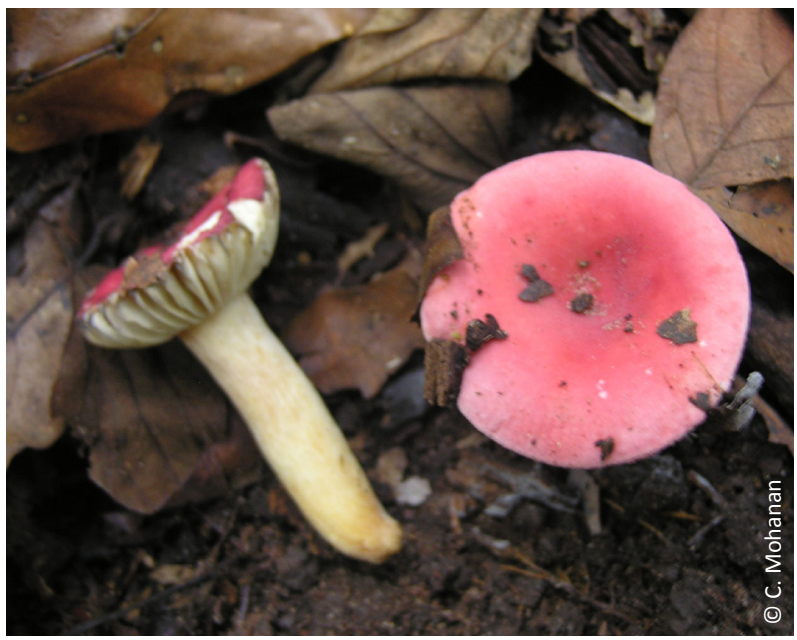

Image 11. Russula martinica

Basidia 25-30 x 10-13 $\mu \mathrm{m}$, clavate, bearing four sterigmata. Lamella-edge heteromorphous but with crowded pseudocystidia. Pseudocystidia numerous both on edge and sides of the lamellae, 38-56 x 13-16 $\mu \mathrm{m}$, ventricose fusoid to acuminate, hyaline, thinwalled, with granular contents. Hymenophoral trama intermixed, hyaline, similar to context. Pileipellis a well developed epicutis of erect or semi-erect thinwalled hyphae, 3-4.5 $\mu \mathrm{m}$ dia., together with scattered dermatocystidia similar to the pseudocystidia.

Russula martinica is distributed in moist-deciduous to evergreen forests and sacred groves of the state. This species occurs solitary or scattered in large groups on soil under Hopea parviflora stands.

Russula michiganensis Shaffer, Brittonia 14(3): 281 (1962) (Image 12)

Specimens examined: KFRI MF: 3284, 18.vi.2009, Kuruva, Begur, Wayanad, Kerala; KFRI MF: 3310, 18.vi.2009, Kuruva, Begur, Wayanad, Kerala; KFRI MF: 1010, 04.v.2008, Iringole Kavu, Perumbavoor, Kerala.

Basidiome small to medium sized. Pileus up to 4-7 cm dia., convex to broadly convex with a central depression becoming uplifted in older ones; surface grayish-brown becoming black on ageing, non-striate. Lamellae adnate, white turning grayish-black to black on handling, more or less crowded with lamellulae of different lengths, with plenty of bifurcations; edge smooth, entire. Context white, up to $5 \mathrm{~mm}$ thick, discolouring blackish on exposure, heteromerous with nests of sphaerocytes. Stipe $2.5-4.5 \mathrm{~cm} \times 9-17 \mathrm{~mm}$, central, equal, solid; surface chalky white, turning black when handled. Annulus absent. Odour not distinctive.

Spores 6-9 x 4-6 $\mu \mathrm{m}$, subglobose to broadly ovoid, 


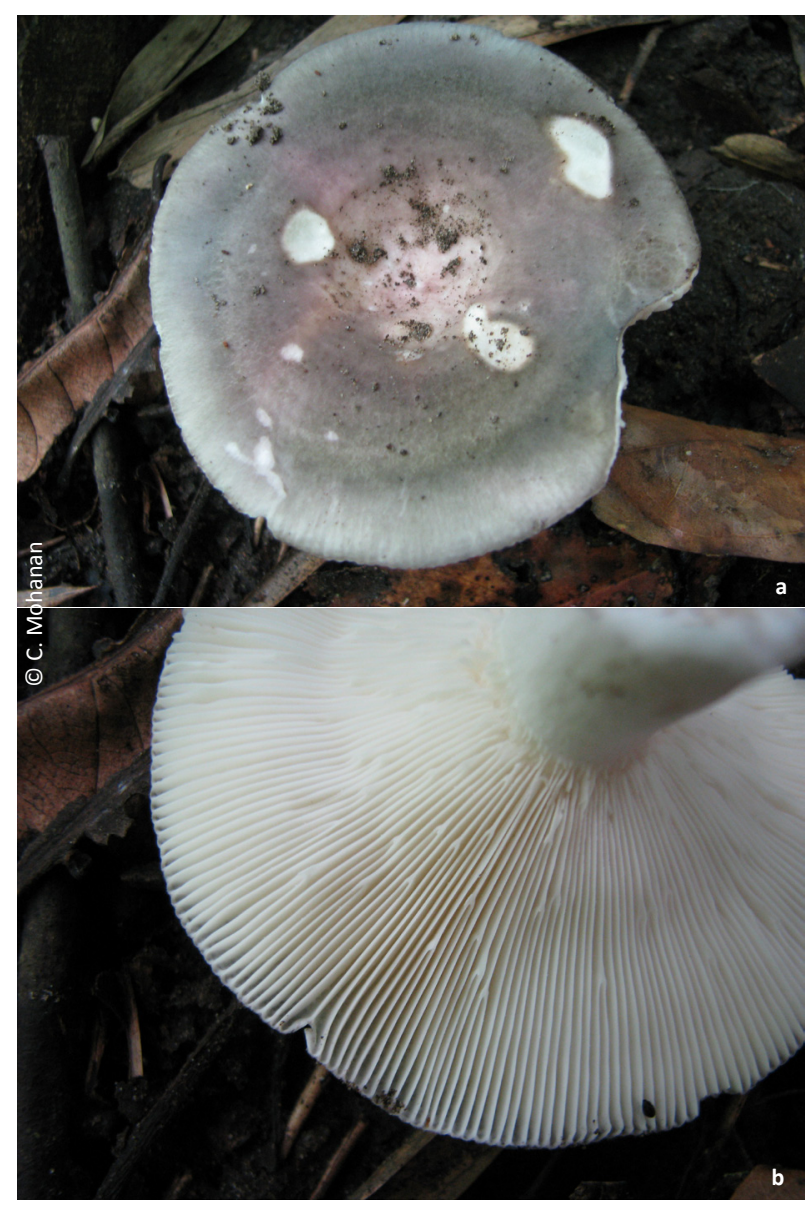

Image 12 a \& b. Russula michiganensis

ornamentation hardly up to $0.5 \mu \mathrm{m}$ high small to medium sized warts and thick and fine ridges are connected to form a partial reticulum; suprahilar plage inamyloid. Basidia clavate, 23-27 x 5-7 $\mu \mathrm{m}$, tetrasporate. Lamellaedge sterile with macrocystidia, and leptocystidia. Macrocystidia 25-30 x 7-11 $\mu \mathrm{m}$, cylindric, thin-walled with refractive contents, concentrated near tip. Pleurocystidia abundant, 30-55 × 6-8 $\mu \mathrm{m}$, subcylindric with capitate apices or rounded with 2 or 3 sub-apical constriction, at times curved basally, with scarcely visible contents, projecting prominently beyond the hymenium, very abundant. Subhymenium pseudoparenchymatous. Hymenophoral trama heteromorphous with sphaerocytes. Pileipellis an interrupted trichodermium.

Russula michiganensis is distributed in moistdeciduous to evergreen forests of the state. This species occurs solitary or scattered in small groups on sandy soil near streams under Hopea ponga, H. parviflora, Hopea sp. Vateria indica, and Diospyros malabarica stands forming an ectomycorrhizal association.
Russula periglypta Berk. \& Broome, J. Linn. Soc., Bot. 11: 566 (1871) (Image 13)

Specimens examined: KFRI MF: 3114, 15.vi.2009, Chandhakkunnu, Nilambur, Kerala.

Basidiome small to medium sized. Pileus $3-5.5 \mathrm{~cm}$ dia., convex depressed at the centre; surface off white, becoming grayish-rose (11B4) with reddish-white (12A2) centre, slightly viscid when moist; margin at first smooth but soon strongly and regularly sulcate, often with tuberculate ridges. Lamellae adnate, pure white, up to $9 \mathrm{~mm}$ wide, crowded, bifurcating, without lamellulae; context white, thinning towards the margin. Stipe 3-5.5 $\mathrm{cm} \times 0.5-1.2 \mathrm{~cm}$, central, solid, attenuated at the base; surface white, smooth and glabrous. Annulus absent.

Spores 8.5-9 x 6.5-7.5 $\mu \mathrm{m}$, broadly ovoid to shortly ellipsoid, strongly amyloid with isolated warts or verrucae, sometimes interconnected forming a partial reticulum; suprahilar area inamyloid. Basidia clavate, 35-44 x 15-16 $\mu \mathrm{m}$, clavate, 4-spored. Lamella-edge heteromorphous to sterile with numerous macrocystidia 35-65 x 8-15 $\mu \mathrm{m}$, fusoid, thin-walled, hyaline or with refractive contents. Subhymenium pseudoparenchymatous. Hymenophoral trama heteromorphous with sphaerocytes. Pileipellis an ixocutis with occasional scattered dermatocystidia.

Russula periglypta is distributed in moist-deciduous to evergreen forests of the state. This species occurs solitary or scattered in large groups on soil often forming a ring under Vateria indica, Hopea parviflora and Diospyros malabarica stands. The absence of lamellulae, the viscid pileus with a tuberculato-pectinate margin and greyish-rose colouration of the cap distinguishes this species.

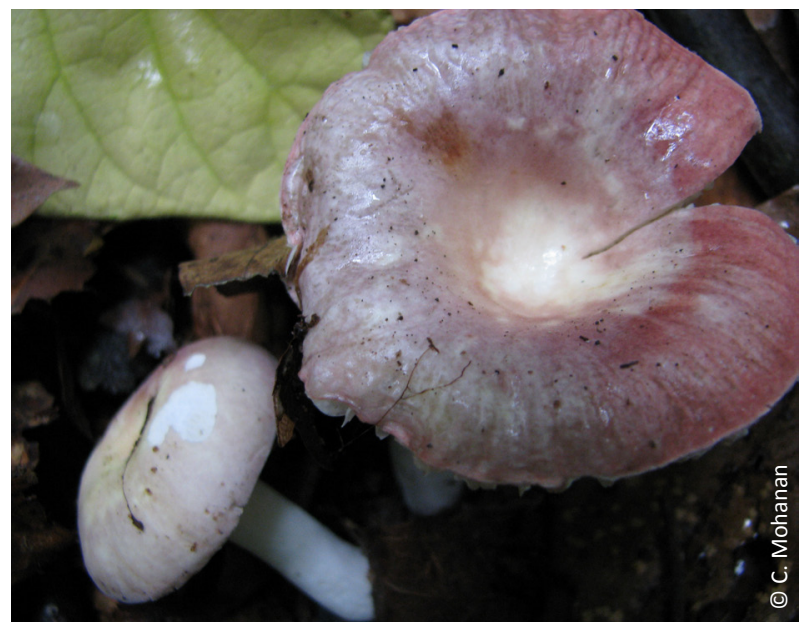

Image 13. Russula periglypta 
Lactarius ignifluus K.B. Vrinda \& C.K. Pradeep, in Vrinda, Pradeep, Mathew \& Abraham, Persoonia 18 (1): 129 (2002) (Image 14)

Specimens examined: KFRI MF: 3452, 04.vii.2009, Iringole Kavu, Perumbavoor, Kerala; KFRI MF: 3424, 20.vi.2009, Chandhanathodu, Periya, Wayanad, Kerala.

Basidiome small sized. Pileus 5-40 mm dia., convex, becoming applanate with an acute umbo, scarlet to pastel red or grayish-red turning bright scarlet when cut or bruised. Context thin, pale-reddish. Lamellae decurrent; pale pink turning scarlet when bruised, subdistant. Stipe central, 1.5-4 cm x 1-3 mm, cylindrical, equal, becoming hollow, concolorous with the pileus pale pink to white at base with abundant aborted, small basidiomes. Latex scarlet, watery, pleasant. Spore-print white. Basidia clavate 35-45 x 6-8.5 $\mu \mathrm{m}$, 4 -spored. Spores globose to sub-globose, 8-10 x 6-8 $\mu \mathrm{m}$, amyloid with ornamentation of ridges and verrucae forming sub-complete reticulum. Cheilocystidia thin-

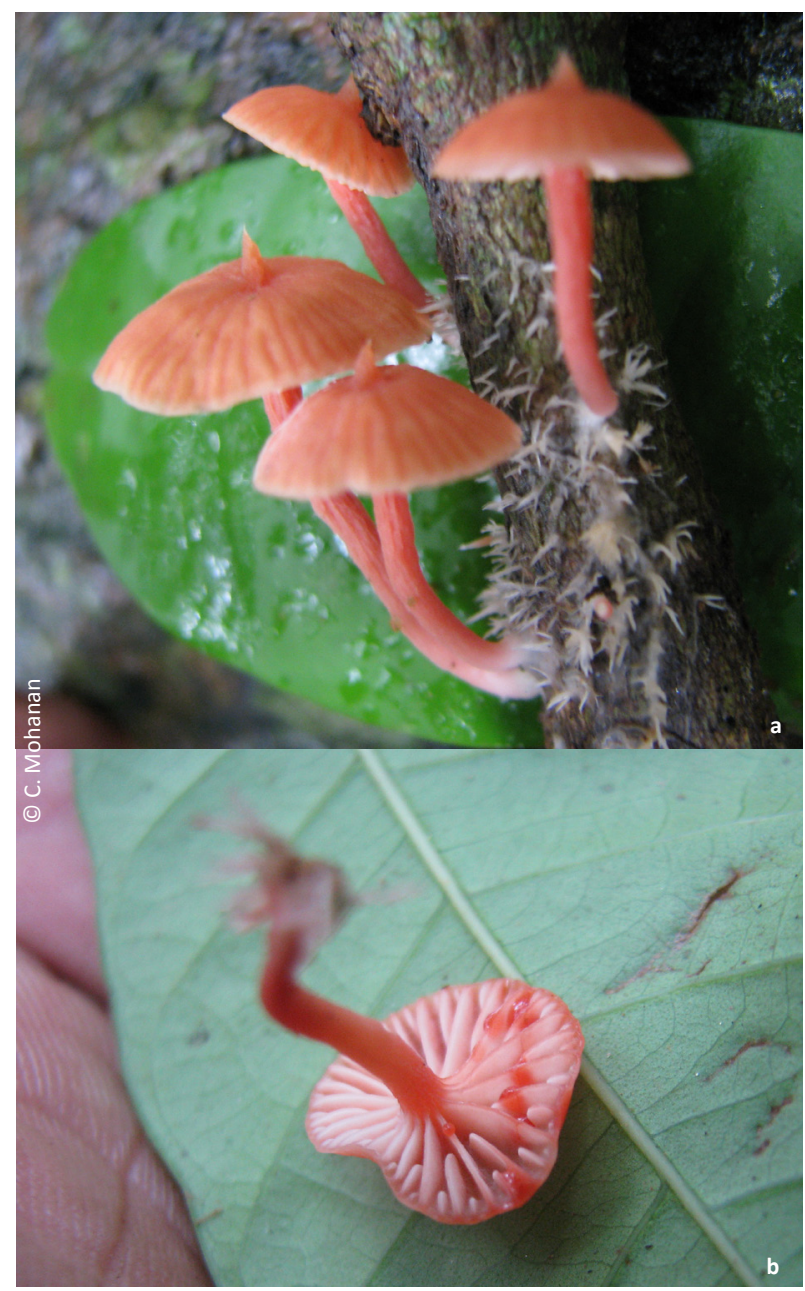

Image 14 a \& b. Lactarius ignifluus walled, clavate, 33-42 x 5-7 $\mu \mathrm{m}$, with dense granular contents. Pleurocystidia clavate, 65-90 x 5-6 $\mu \mathrm{m}$ with dense granular contents. Hymenophoral trama hyaline to pale pinkish, heteromerous, of narrow hyphae, 5-20 $\mu \mathrm{m}$ dia., intermixed with numerous sphaerocytes and laticiferous hyphae. Subhymenial layer well-developed, pseudoparenchymatous. Pileipellis a dense and continuous trichodermial palisade, 25-40 $\mu \mathrm{m}$ thick, of erect or semi-erect, thin-walled, sinuous-cylindric hairs $20-40 \times 3-5 \mu \mathrm{m}$, with an obtusely rounded apex, pale pinkish-granular contents, occasional laticiferous hyphae present.

Lactarius ignifluus is widely distributed in semievergreen to evergreen forests of the Western Ghats, Kerala, and occurs solitary or scattered in small clusters on soil and on basal part of the stem. This species forms an ectomycorrhizal association with Hopea ponga, Vateria indica trees.

Lactarius nebulosus Pegler, in Pegler \& Fiard, Kew Bull. 33(4): 610 (1979) (Image 15)

Specimens examined: KFRI MF: 3304 and 3624, 18.vi.2009 and 17.ix.2009, Kuruva, Begur, Wayanad, Kerala.

Basidiome small to medium sized. Pileus $2.5-4.5 \mathrm{~cm}$ dia., fleshy, at first convex with a more or less umbilicate centre than applanate or slightly depressed; surface whitish with broad pale grayish-brown with grayishbrown areas, azonate, dry, glabrous to subvelutinate, often somewhat rugose; margin horizontal, acute, undulate, not striate. Lamellae adnato-decurrent, white, staining pale brown or bruising, up to $4 \mathrm{~mm}$ wide, rather distant, with numerous lamellulae and frequently furcate especially near the margin. Stipe 2-4 cm x 7-12 mm, often very short, cylindric, equal, firm, solid; surface pure white, bruising cinnamon brown, subpruinose, glabrescent. Context up to $5 \mathrm{~mm}$ thick at the disk, firm, pure white, discolouring brown on exposure, heteromerous, of thin-walled hyphae, 2-5 $\mu \mathrm{m}$ dia., interwoven with groups of sphaerocytes, 9-20 $\mu \mathrm{m}$ dia., and abundant, hyaline, refractive laticiferous hyphae, 3-10 $\mu \mathrm{m}$ dia. Latex abundant, aqueous, white.

Spores 9-11 x 8-10 $\mu \mathrm{m}$, subglobose, ovoid or short ellipsoid, hyaline, with a strongly amyloid ornamentation of isolated, hemispherical verrucae, 0.6-1.5 x 0.4-1.5 $\mu \mathrm{m}$, suprahilar plage inamyloid although a small, central amyloid spot often visible; hilar appendix 1.5-2 x 1-1.5 $\mu \mathrm{m}$. Basidia 35-42 x 10-13 $\mu \mathrm{m}$, elongate clavate, hyaline, bearing two or four sterigmata; sterigmata up to $5 \mu \mathrm{m}$ long. Lamella-edge fertile or heteromorphous, with scattered pseudocystidia. Pseudocystidia very abundant, 35-45 x 


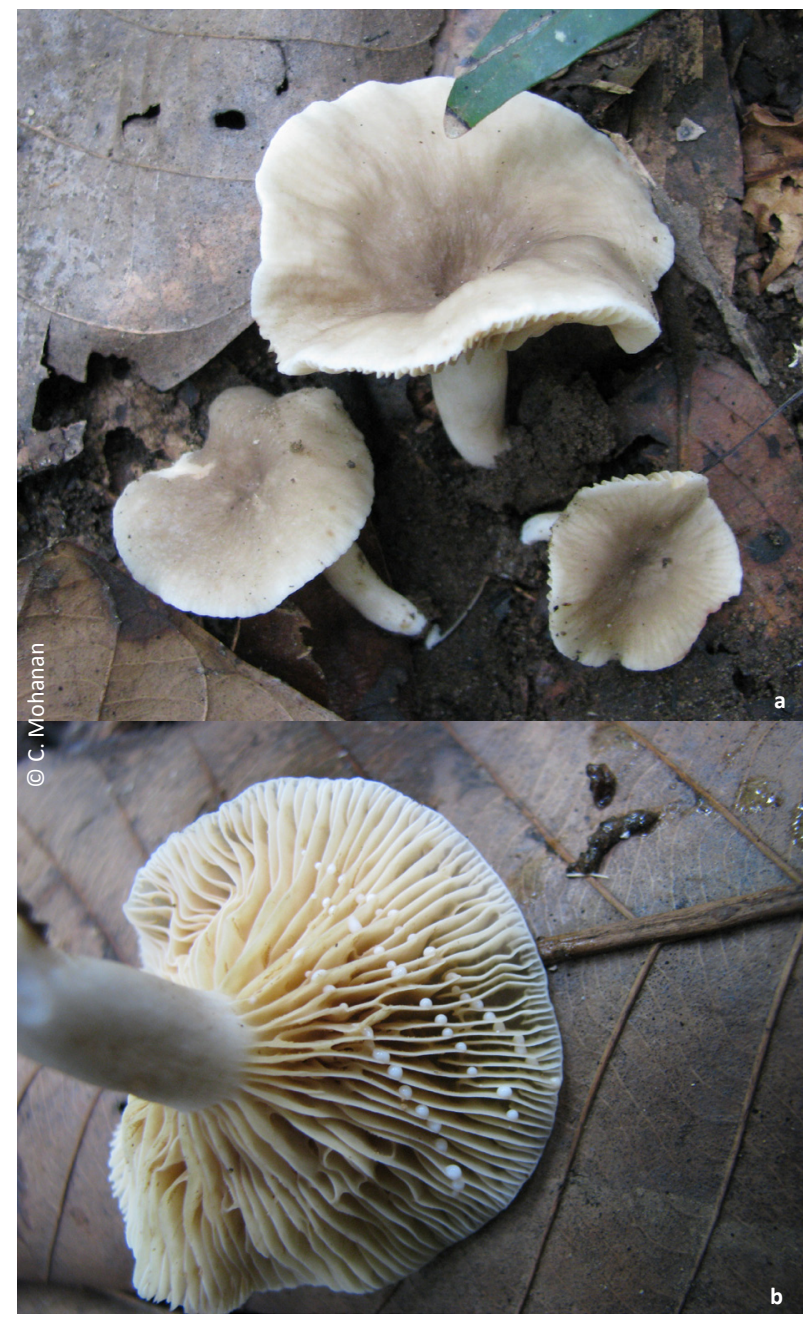

Image 15 a \& b. Lactarius nebulosus

11-15 $\mu \mathrm{m}$, lanceolate-fusoid, with an acute, constricted or mucronate apex, thin-walled, hyaline, with oleaginous to granular, refractive contents, projecting beyond the basidia. Hymenophoral trama hyaline, heteromerous, of narrow hyphae intermixed with numerous sphaerocytes and laticiferous hyphae. Subhymenial layer welldeveloped pseudoparenchymatous. Pileipellis a dense and continuous trichodermial palisade, 30-60 $\mu \mathrm{m}$ thick, of erect or semi-erect, thin-walled, sinuous-cylindric hairs $30-50 \times 2.5-5 \mu \mathrm{m}$, with an obtusely rounded apex, hyaline or occasionally with grayish vacuolar contents, occasional laticiferous hyphae present.

Lactarius nebulosus is widely distributed in semievergreen to evergreen forests of the Western Ghats, Kerala, and occurs solitary or scattered in small clusters on soil.

\section{Discussion}

The family Russulaceae contains 1243 species (Kirk et al. 2008). The family is dominated by the two well-known genera Russula and Lactarius. Members are widespread from the Arctic and Antarctic regions through to the tropics, both in the old and new world. The genera with gasteroid or hypogeous gasteroid basidiomes have traditionally been separated from the agaricoid genera. However, recent molecular analysis has shown that the derived gasteroid form is relatively recent and appears to justify an integration of the gasteroid taxa in the agaricoid genera, Russula and Lactarius (Binder \& Bresinsky 2002). Further, as more tropical taxa are discovered the generic boundaries in the family are eroded. The preliminary study indicates the strong likelihood that Lactarius evolved from Russula, that the two genera may be very closely related in the Russula brevipes-Lactarius piperatus area, and the previous suggestions that the associated gasteroid genera belong in the family are correct (Miller et al. 2001; Eberhardt 2002; Binder \& Bresinsky 2002; Miller \& Buyck 2002; Moncalvo et al. 2002). Presence of large spherical cells, 'sphaerocysts' in stipe is an important characteristic feature distinguishing the members of Russulaceae from other mushrooms. In Russula and Lactarius, the stipe breaks like the flesh of an apple, whilst in most other families it only breaks into fibres.

The genus Russula sometimes known as 'brittle gills', comprises about 750 species, the majority of which are quite difficult to identify. They have splitting gills and do not exude a milky substance at cut surfaces, contrary to the genus Lactarius. There are several edible species, while a few are toxic, such as red caped species like $R$. emetica, $R$. sordonia, $R$. nobilis, etc. Most of the species form an ectomycorrhizal association with native trees. So far, only two species, Russula indica and $R$. leelavathyi have earlier been reported from Kerala (Sathe \& Daniel 1980; Vrinda et al. 1997). Of the 13 species of Russula recorded herein 12 species, namely, Russula aciculocystis, $R$. adusta, $R$. atropurpurea, $R$. cinerella, $R$. congoana, $R$. delicula, $R$. hygrophytica, $R$. luteotacta, $R$. mariae, $R$. martinica, $R$. michiganensis and $R$. periglypta are new records for Kerala.

The genus Lactarius or 'milk caps' is a large genus of ectomycorrhizal fungi, characterized by caps and stalks that exude a milky latex when cut; this liquid may be white, yellow, orange, red, or lilac, and may develop its final colour only after exposure to air. Most of the species form an ectomycorrhizal association with native tree species. A few are edible. So far, only Lactarius ignifluus, a salmon coloured latex exuding species has 
earlier been reported from Kerala (Pradeep et al. 2002). Lactarius nebulosus, a white coloured latex exuding species, recorded herein is a new record for the Western Ghats.

\section{References}

Binder, M. \& A. Bresinsky (2002). Derivation of a polymorphic lineage of gasteromycetes from boletoid ancestors. Mycologia 94(1): 85-98.

Eberhardt, U. (2002). Molecular kinship analyses of the agaricoid Russulaceae. Correspondance with mycorrhizal anatomy and sporocarp features in the genus Russula. Mycological Progress 1(2): 201-223; http://dx.doi.org/10.1007/s11557-006-0019-6

Kirk, P.M., P.F. Cannon, D.W. Minter \& J.A. Staplers (eds.) (2008) Ainsworth \& Bisby's Dictionary of the Fungi. Tenth Edition, CAB International, Wallingford, U.K., 771pp.

Miller, S.L. \& B. Buyck (2002). Molecular phylogeny of the genus Russula in Europe with a comparison of modern infrageneric classifications. Mycological Research 106(3): 259-276; http:// dx.doi.org/10.1017/S0953756202005610

Miller, S.L., T.M. McClean, J.F. Walker \& B. Buycket (2001). A molecular phylogeny of the Russulales including agaricoid, gasteroid and pleurotoid taxa. Mycologia 93(2): 344-354.

Mohanan, C. (2011). Macrofungi of Kerala. KFRI Handbook No. 27. Kerala Forest Research Institute, Peechi, Kerala, India, 597pp.

Moncalvo, J.M., R. Vilgalys, S.A. Redhead, J.E. Johnson, T.Y. James, M.C. Aime, V. Hofstetter, S.J.W. Verduin, E. Larsson, T.J. Baroni, R.G. Thorn, S. Jacobsson, H. Clemencon \& O.K. Miller Jr. (2002). One hundred and seventeen clades of euagarics. Molecular Phylogenetics and Evolution 23(3): 357-400; http://dx.doi. org/10.1016/S1055-7903(02)00027-1

Pradeep, C.K., K.B. Vrinda \& T.K. Abraham (2002). Lactarius ignifluus a new species of Lactarius from Kerala State, India. Persoonia 18(1): $129-135$.

Sathe, A.V. \& J. Daniel (1980). Agaricales (Mushrooms) of Kerala State. MACS Monograph 1: 75-108.

Vrinda, K.B., Pradeep, C.K. \& T.K. Abraham (1997). A new species of Russula from Kerala, India. Mycotaxon 62: 389-393. 